\title{
PENGEMBANGAN MODUL FISIKA BERBASIS CTL (CONTEXTUAL TEACHING AND LEARNING) PADA MATERI DINAMIKA PARTIKEL UNTUK MENINGKATKAN KETERAMPILAN BERPIKIR KRITIS SISWA KELAS X SMAN 1 NGAWI
}

\author{
Alfi Anafidah ${ }^{1}$, Sarwanto $^{2}$, Mohammad Masykuri ${ }^{3}$ \\ ${ }^{1}$ Program Studi Magister Pendidikan Sains FKIP Universitas Sebelas Maret \\ Surakarta, 57126, Indonesia \\ alfia_moslem@yahoo.co.id \\ ${ }^{2}$ Program Studi Magister Pendidikan Sains FKIP Universitas Sebelas Maret \\ Surakarta, 57126, Indonesia \\ sarwanto@fkip.uns.ac.id \\ ${ }^{3}$ Program Studi Magister Pendidikan Sains FKIP Universitas Sebelas Maret \\ Surakarta, 57126, Indonesia \\ mmasykuri.@yahoo.com
}

\begin{abstract}
Abstrak
Penelitian ini bertujuan untuk mengetahui: (1) karakteristik modul fisika berbasis CTL; (2) kelayakan modul fisika berbasis CTL; dan (3) efektivitas modul fisika berbasis CTL pada materi dinamika partikel. Metode penelitian yang digunakan adalah Research and Development (R\&D). Pengembangan modul mengacu pada model Thiagarajan yang terdiri dari empat tahap yang dikenal dengan model 4-D (four D model) dengan tahapan Define, Design, Develop, dan Disseminate. Tahap define berupa analisis kebutuhan, tahap design berupa penyusunan draf modul, tahap develop berupa validasi draf modul oleh 2 dosen, 2 guru fisika, dan 2 peer review, setelah valid dilakukan uji coba kecil pada 12 siswa dan diimplementasikan pada skala luas. Tahap terakhir yaitu disseminate yang dilakukan pada 5 guru fisika di kabupaten Ngawi Jawa Timur. Pengumpulan data menggunakan angket, lembar observasi, lembar validasi, dan instrumen tes. Teknik analisis data menggunakan analisis deskriptif kualitatif. Peningkatan keterampilan berpikir kritis siswa dianalisis dengan uji paired sample ttest. Hasil penelitian menunjukkan bahwa: (1) modul fisika berbasis CTL dikembangkan dengan model 4-D dengan tujuh karakteristik pembelajaran CTL yaitu constructivism, inquiry, questioning, learning community, modelling, reflection dan autentic assessment; (2) kelayakan modul fisika berbasis CTL berkategori sangat baik setelah dilakukan validasi; (3) keterampilan berpikir kritis siswa mengalami peningkatan setelah mengikuti proses pembelajaran dengan menggunakan modul fisika berbasis CTL sebesar 0,36 dengan kategori sedang.
\end{abstract}

Kata Kunci: Modul Fisika, Contextual Teaching and Learning , Keterampilan Berpikir Kritis.

\section{Pendahuluan}

Kurikulum 2013 dikembangkan dengan landasan filosofis yang memberikan dasar bagi pengembangan seluruh potensi peserta didik menjadi manusia Indonesia berkualitas yang tercantum dalam tujuan pendidikan nasional. Implementasi kurikulum 2013 pada pembelajaran fisika khususnya pada jenjang SMA sebagai wahana mensyukuri nikmat Tuhan akan ciptaanNya melalui pembelajaran fisika. Pembelajaran fisika dalam kurikulum 2013 menggunakan pendekatan ilmiah dengan keterampilan berpikir siswa dapat terasah dan dikembangkan melalui pembelajaran dengan langkah-langkah ilmiah. Salinan lampiran Permendikbud nomor 69 tahun 2013 menyatakan keikutsertaan Indonesia dalam studi International Trends in International Mathematics and Science Study (TIMSS) sejak tahun 1999 menunjukkan bahwa capaian anak-anak Indonesia kurang menggembirakan dalam beberapa kali laporan yang dikeluarkan TIMSS. Hasil survei pembelajaran IPA oleh TIMSS tahun 2011 menunjukkan Indonesia menempati peringkat 
40 dari 42 negara yang terlibat, dengan rerata 606 masih dibawah rerata skor internasional (TIMSS, 2011). Karakteristik soal-soal yang diujikan di TIMSS cenderung mengujikan aspek penalaran dan pemecahan masalah. Kurikulum IPA khususnya fisika sendiri masih banyak menekankan keterampilan dasar menghitung (basic skills) yang bersifat prosedural.

Fisika bukan hanya memiliki sumbangan nyata terhadap perkembangan teknologi, namun juga mendidik siswa di dalam pembelajarannya untuk bertindak atas dasar pemikiran kritis, analitis, logis, rasional, cermat, dan sistematis, serta menanamkan kebiasaan berpikir dan berperilaku ilmiah yang kritis, kreatif dan mandiri (Permendiknas No. 22 tahun 2006 tentang Standar Isi). Hakekat fisika merupakan kumpulan pengetahuan, cara berpikir dan penyelidikan. Fisika adalah ilmu pengetahuan yang menggunakan metode ilmiah dalam prosesnya (Wirtha dan Rapi, 2008). Penekanan pembelajaran sains, dalam hal ini fisika di sekolah-sekolah masih terbatas pada penguasaan kumpulan pengetahuan yang berupa fakta-fakta, konsep-konsep atau prinsip-prinsip. Perlu adanya perubahan dalam cara belajar sains dari diberi tahu menjadi mencari tahu, dari belajar untuk memahami konsep sains menjadi belajar untuk menguasai proses sains (BNSP, 2006). Secara umum pembelajaran yang dilaksanakan oleh guru masih bersifat teacher center dan siswa kurang diberikan kesempatan untuk mengembangkan keterampilan berpikirnya.

Antusias siswa untuk belajar fisika masih rendah, hal ini sesuai dengan hasil observasi di SMAN 1 Ngawi kelas X MIA terlihat hampir $62 \%$ siswa kurang memperhatikan penjelasan guru sementara $38 \%$ siswa mendengarkan dan mencatat penjelasan guru pada papan tulis. Siswa dalam belajar fisika hanya mencatat, mendengarkan dan cenderung pasif, serta kurangnya pertanyaan atau penyampaian pendapat mengakibatkan keterampilan berpikir kritis siswa masih belum muncul dan suasana kelas menjadi kurang hidup.

Hasil observasi dengan siswa kelas $\mathrm{X}$ MIA SMAN 1 Ngawi menyatakan bahwa siswa SMAN 1 Ngawi memiliki keterampilan berpikir kritis masih rendah. Hal ini ditunjukkan saat siswa menyelesaikan soal fisika yang diberikan guru, siswa menjawab soal belum disertai dengan pemahaman yang mendalam terkait dengan soal yang diberikan. Selain itu keengganan siswa dalam bertanya saat diberi kesempatan oleh guru menunjukkan bahwa siswa belum memiliki sejumlah keterampilan yang seharusnya dimiliki oleh seorang pemikir kritis. Hal senada diutarakan Gunawan (2010), bahwa pembelajaran fisika di sekolah belum mengembangkan keterampilan berpikir dan mengembangkan pemikiran, dalam menjawab soal siswa cenderung mengutip dari buku tanpa mengemukakan pendapat atau analisisnya sehingga lebih menekankan pada aspek hafalan. Pembelajaran belum mengembangkan keterampilan berpikir.

Adanya kurikulum 2013 salah satu tujuannya adalah siswa mampu menggunakan logikanya untuk berpikir kritis. SMAN 1 Ngawi telah menggunakan kurikulum 2013, namun dalam kenyataannya penerapan yang terdapat dalam kurikulum 2013 masih sebatas teori. Pengaplikasian dalam pembelajaran masih seperti biasanya yaitu dengan ceramah, jarang memakai media interaktif seperti modul, video atau powerpoint, maupun praktikum. Padahal kurikulum 2013 menuntut adanya peran aktif siswa dalam pembelajaran yaitu dengan pembelajaran berbasis scientific. Peran guru dalam pembelajaran fisika adalah memfasilitasi siswa untuk belajar dan berfikir. Menurut Jozua Subandar dalam Megarati (2010) ada beberapa hal yang perlu dikuasai dan dilakukan oleh guru agar proses berpikir siswa dapat berlangsung yaitu guru harus menggunakan teknik prompting, probing, scafolding, dan cognitive conflict.

Berdasarkan pada masalah yang terjadi pada siswa kelas X SMAN 1 Ngawi maka perlu untuk dilakukan pengkajian terhadap proses pembelajaran fisika yang selama ini diterapkan. Salah satu caranya yaitu dengan menerapkan pembelajaran yang sesuai dengan hakikat pembelajaran fisika yang berbasis scientific salah satunya adalah pembelajaran kontekstual. 
Berpikir merupakan suatu aktivitas untuk membantu memformulasikan atau memecahkan suatu masalah, membuat suatu keputusan, atau memenuhi hasrat keingitahuan. Keterampilan berpikir secara garis besar terbagi menjadi dua yaitu berpikir kritis dan kreatif. Berpikir kritis merupakan salah satu kecakapan berpikir yang harus dimiliki peserta didik dalam menyelesaikan suatu permasalahan. Siswa yang keterampilan berpikir siswa yang kritis dapat menunjang kreativitas siswa dalam mengembangkan keterampilannya dalam menghadapi masalah. Namun, pada kenyataannya kecakapan berpikir ini belum ditangani secara sungguh-sungguh oleh guru di sekolah. Hal ini mendukung penemuan yang dilakukan oleh Rofiudin (2000) dan Guilford cit Munandar (2009: 31) menyatakan bahwa rendahnya keterampilan berpikir kritis yang dimiliki oleh lulusan pendidikan dasar sampai perguruan tinggi karena pendidikan belum ditangani dengan baik dan masih kurang mendapatkan perhatian dalam pendidikan.

Hasil penelitian Muhfahroyin (2009: 3) berpikir kritis merupakan proses yang melibatkan operasi mental seperti induksi, deduksi, klasifikasi, dan penalaran. Kunci berpikir kritis adalah mengembangkan pendekatan impersonal yang memperhatikan argumentasi dan fakta sejalan dengan pandangan, pendapat, dan perasaan personal. Ennis dalam Costa (1985), menyebutkan ada lima aspek berpikir kritis, yaitu a) memberi penjelasan dasar, b) membangun keterampilan dasar, c) menyimpulkan, d) memberi penjelasan lanjut, dan e) mengatur strategi dan taktik. Berdasarkan hal tersebut, berpikir kritis adalah keterampilan berpikir yang berpotensi meningkatkan daya analitis kritis siswa. Peningkatan daya analitis kritis siswa sangat berkaitan dengan peningkatan kemampuan intelektual siswa. Oleh karena itu, menumbuhkembangkan keterampilan berpikir kritis siswa dalam pembelajaran merupakan upaya untuk meningkatkan hasil belajar siswa.

Modul merupakan salah satu bentuk bahan ajar sistematis yang dikemas secara utuh serta di dalamnya memuat seperangkat alat belajar yang terencana dan didesain untuk membantu siswa agar menguasai tujuan belajar yang spesifik (Suaidinmath, 2010). Modul memiliki sifat membantu dan mendorong pembacanya untuk membelajarkan diri sendiri (self instructional) dan tidak bergantung pada media lain (stand alone) dalam penggunaanya (Hamdani, 2011: 20).

Pendekatan pembelajaran kontekstual (CTL) menurut Muslich (2007) adalah konsep belajar yang membantu guru mengkaitkan antara materi yang diajarkan dengan situasi dunia nyata siswa sehingga siswa mampu menghubungkan dan menerapkan kompetensi hasil belajar dalam kehidupan sehari-hari.

Penggunaan modul pembelajaran fisika berbasis CTL memberikan kesempatan pada pembelajaran dengan menyampaikan pesan dari pengirim ke penerima sehingga dapat merangsang pikiran, perasaan, perhatian, minat siswa sehingga proses pembelajaran menjadi menyenangkan dan menarik. Dengan memunculkan kejadian-kejadian fisika dalam kehidupan sehari-hari dapat dijadikan sebagai umpan kepada siswa agar memahami, menelusuri, dan mencari tahu konsep dasar keilmuannya melalui percobaan. Kejadian fisika di alam diikuti munculnya pertanyaan yang disajikan diawal pembelajaran sebagai stimulus untuk mendorong siswa dalam mengembangkan keterampilan berpikir kritis dalam penyelesaian masalah. Siswa secara berkelompok bekerjasama untuk memecahkan masalah melalui percobaan dengan menggunakan langkah-langkah ilmiah dan mempresentasikan hasilnya. Hasil yang diperoleh dari proses ilmiah mengembangkan pola fikir siswa menjadi lebih kritis dalam menyelesaikan setiap permasalahan.

Penelitian ini bertujuan untuk: (1) mengetahui karakteristik modul fisika berbasis CTL; (2) mengetahui kelayakan modul fisika berbasis CTL; dan (3) mengetahui efektivitas modul fisika berbasis CTL pada materi dinamika partikel.

\section{Metode Penelitian}

Tempat penelitian dilaksanakan di SMAN 1 Ngawi dengan alamat Jl. A. Yani No 45 Ngawi, Jawa Timur. Waktu penelitian 
dilaksanakan pada bulan Maret 2014 sampai dengan Juli 2015 mulai dari tahap persiapan yaitu dengan penyusunan angket analisis kebutuhan yang diberikan kepada guru fisika dan siswa hingga tahap penyusunan hasil.

Penelitian ini merupakan penelitian Research and Development $(\mathrm{R} \& \mathrm{D})$ yang bertujuan untuk mengembangkan modul pembelajaran fisika berbasis CTL (Contextual Teaching and Learning) dengan tema dinamika partikel untuk mengetahui kualitas modul dan meningkatkan keterampilan berpikir kritis kelas X MIA-1 SMAN 1 Ngawi.

Prosedur pengembangan modul pembelajaran fisika berbasis CTL menggunakan model Thiagarajan yang terdiri dari 4 tahap yang dikenal dengan model 4-D (four $D$ model) yang meliputi tahap pendefinisian (define), perancangan (design), pengembangan (develop), dan penyebaran (disseminate).

Instrumen yang digunakan berupa angket, lembar observasi, lembar validasi, dan instrumen tes. Angket digunakan untuk mengumpulkan data kebutuhan guru dan siswa. Lembar observasi digunakan untuk mengetahui sumber daya dan inventarisasi sumber belajar di sekolah yang meliputi ketersediaan fasilitas pendukung, laboratorium, perpustakaan, serta sumber daya sekolah. Lembar validasi digunakan untuk mengumpulkan data mengenai kelayakan modul fisika berbasis CTL yang dikembangkan dan ditinjau dari aspek materi, media dan bahasa. Lembar validasi diisi oleh dosen ahli, guru fisika, dan peer review. Instrumen tes yang digunakan adalah tes awal (pretest) dan tes akhir (posttest). Tes berbentuk uraian sebanyak 12 soal yang digunakan untuk mengukur keterampilan berpikir kritis sebelum dan setelah menggunakan modul fisika berbasis CTL. Sebelum instrumen tes diujikan, instrumen diuji validitas, reliabilitas, daya pembeda, dan tingkat kesukaran.

Tahap pendefinisian (Define)
bertujuan untuk menentukan dan
mendefinisikan kebutuhan-kebutuhan dalam
pembelajaran fisika di sekolah dengan
memperhatikan kebutuhan siswa dan guru,
kurikulum yang berlaku, dan kondisi sekolah.

Tahap pendefinisian dimulai dari pra penelitian sebagai kegiatan awal pengembangan. Tahap ini dilakukan dengan melakukan observasi di sekolah serta penyebaran angket kebutuhan kepada guru mata pelajaran fisika dan siswa.

Angket kebutuhan siswa dan guru yang telah disebarkan kemudian di analisis. Hasil analisis angket pengungkap kebutuhan tersebut digunakan sebagai dasar pengembangan modul. Modul yang dikembangkan merupakan modul utama sebagai proses penuntun kegiatan belajar siswa dengan menerapkan pembelajaran CTL.

Tahap perancangan (Design) dilakukan untuk menentukan desain awal dari modul fisika berbais CTL dengan memperhatikan komponen materi, media dan bahasa. Desain awal tersebut dikonsultasikan kepada dosen pembimbing sehingga diperoleh draft I modul. Draf I modul terdiri dari cover, pendahuluan, peta konsep, materi prasyarat, kegiatan belajar yang terdiri dari pembelajaran 1 sampai dengan 3, rangkuman, lembar evaluasi, glosarium, dan daftar pustaka.

Tahap pengembangan (Develop) dimulai dari validasi draf I modul dengan melibatkan 2 dosen ahli, 2 guru mata pelajaran fisika SMA, dan 2 peer preview (teman sejawat) yang sedang mengembangkan produk penelitian berupa modul pembelajaran. Setelah draf I modul divalidasi dilanjutkan dengan revisi sehingga diperoleh draf II modul.

Tahap penyebaran (Disseminate) merupakan tahap penggunaan modul fisika berasis CTL dalam skala yang lebih luas. Dalam penelitian ini tahap penyebaran diterapkan pada guru mata pelajaran fisika SMA negeri dan swasta kelas X di Kabupaten Ngawi. Tujuan dari tahap penyebaran adalah untuk mengetahui tanggapan dari guru fisika tentang modul fisika berbasis CTL pada materi dinamika partikel.

Data penelitian yang berupa angket, lembar observasi, dan lembar validasi dianalisis dengan menggunakan teknik analisis deskriptif kualitatif. Sedangkan data hasil tes dianalisis menggunakan gain faktor ternormalisasi (N-Gain). Data tes diperoleh dari pretest dan postest yang terdiri dari 12 butir soal uraian. Tes ini digunakan untuk 
mengukur keterampilan berpikir kritis siswa terhadap materi fisika. Soal yang gunakan sebagai instrumen pengambil data selain berdasarkan indikator tujuan belajar penguasaan konsep fisika juga didasarkan pada indikator keterampilan berpikir kritis.

\section{Hasil Penelitian dan Pembahasan}

Hasil tahap pendefinisian (Define) dilakukan dengan studi pustaka dan survei lapangan. Berdasarkan hasil studi pustaka SMAN 1 Ngawi mulai menerapkan kurikulum 2013 pada tahun ajaran 2013/2014 di kelas X. Kurikulum 2013 mengharuskan pembelajaran fisika dilaksanakan dengan pendekatan scientific dan mengacu pada kompetensi inti yang telah ditetapkan pada kurikulum 2013, sehingga dihasilkan lulusan yang mempunyai kompetensi dari segi sikap, pengetahuan, dan keterampilan. Survei lapangan dilakukan dengan menyebarkan angket kebutuhan kepada dua guru fisika dan 17 siswa kelas XI SMAN 1 Ngawi. Analisis kebutuhan dilakukan pada siswa kelas XI karena siswa telah mengikuti pembelajaran dinamika partikel di kelas $X$. Angket kebutuhan guru terdiri dari empat aspek yaitu penggunaan bahan belajar, pelaksanaan pembelajaran dikelas, keterbatasan dan kesulitan yang dirasakan guru di saat mengajar serta kebutuhan media pembelajaran alternatif pada materi dinamika partikel.

Analisis terhadap angket kebutuhan guru dan siswa menunjukkan bahwa media belajar yang berupa buku teks atau modul untuk menunjang proses belajar masih terbatas. Adapun buku teks yang tersedia belum mampu membuat siswa aktif terlibat dalam pembelajaran, sehingga keterampilan berpikir siswa belum dikembangkan secara maksimal. Guru dan siswa menghendaki adanya pengembangan modul pembelajaran yang mampu membuat siswa memahami konsep materi dengan mudah dan menarik, terlibat aktif pada pembelajaran, mendorong siswa untuk belajar mandiri, serta dapat mengasah perkembangan keterampilan berpikir kritis siswa.
Hasil tahap perancangan (Design) dilaksanakan setelah dilakukan analisis kebutuhan awal yang menunjukkan diperlukannya pengembangan modul fisika berbasis CTL. Tahap perancangan modul meliputi: (a) penyusunan Garis Besar Isi Modul (GBIM), (b) pemilihan format modul yang diadaptasi dari format kriteria modul yang diterbitkan oleh Pusat Teknologi Informasi dan Komunikasi Pendidikan (Pustekkom) Depdiknas, (c) membuat matriks hubungan antara pendekatan CTL, keterampilan berpikir kritis, kurikulum 2013, dan materi dinamika partikel, dan (d) membuat desain awal modul. Tahap desain menghasilkan draf I modul yang didesain dengan mengimplementasikan tujuh komponen pembelajaran CTL dan lima aspek keterampilan berpikir kritis ke dalam setiap kegiatan belajar.

Hasil tahap pengembangan (Develop) produk meliputi validasi materi, media dan bahasa.

Tabel 1. Hasil Analisis Validasi Modul Komponen

\begin{tabular}{|c|c|c|c|c|}
\hline \multicolumn{5}{|c|}{ Materi } \\
\hline & dator & Skor & Rata & Kriteria \\
\hline \multirow{2}{*}{ Dosen } & Dosen 1 & 68 & \multirow{2}{*}{70} & \multirow{2}{*}{ Baik } \\
\hline & Dosen 2 & 72 & & \\
\hline \multirow{2}{*}{ Guru } & Guru 1 & 78 & \multirow{2}{*}{77,5} & \multirow{2}{*}{ Sangat Baik } \\
\hline & Guru 2 & 77 & & \\
\hline \multirow{3}{*}{$\begin{array}{l}\text { Peer } \\
\text { Review }\end{array}$} & PR 1 & 75 & \multirow{2}{*}{76,5} & \multirow{2}{*}{ Sangat Baik } \\
\hline & PR2 & 79 & & \\
\hline & ta-rata To & & 74,66 & Sangat Baik \\
\hline
\end{tabular}

Tabel 1 menunjukkan validasi modul pada komponen materi oleh setiap validator. Hasil validasi modul pada kelayakan materi diperoleh skor rata-rata total 74,66 dari skor maksimum 88 dengan kategori sangat baik. Skor diperoleh dari 4 aspek kelayakan materi yang meliputi: (1) kesesuaian uraian materi dengan KI dan KD (2) keakuratan materi (3) kemutakhiran materi dan (4) paktikum.

Hasil penelitian pada komponen media dapat dilihat pada Tabel 2.

Tabel 2. Hasil Analisis Validasi Modul Komponen Media

\begin{tabular}{|c|c|c|c|c|}
\hline \multicolumn{2}{|c|}{ Validator } & Skor & Rata & Kriteria \\
\hline \multirow{2}{*}{ Dosen } & Dosen 1 & 36 & \multirow{2}{*}{35} & \multirow{2}{*}{ Baik } \\
\hline & Dosen 2 & 34 & & \\
\hline \multirow{2}{*}{ Guru } & Guru 1 & 38 & \multirow{2}{*}{38,5} & \multirow{2}{*}{ Sangat Baik } \\
\hline & Guru 2 & 39 & & \\
\hline \multirow{3}{*}{$\begin{array}{l}\text { Peer } \\
\text { Review }\end{array}$} & PRI & 40 & \multirow{2}{*}{41,5} & \multirow{2}{*}{ Sangat Baik } \\
\hline & $P R 2$ & 43 & & \\
\hline & Rata-rata T & & 38,33 & Sangat Baik \\
\hline
\end{tabular}


Tabel 2 menunjukkan validasi modul pada komponen media oleh setiap validator. Hasil validasi modul pada kelayakan media diperoleh skor rata-rata total 38,33 dari skor maksimum 44 dengan kategori sangat baik. Skor diperoleh dari 3 aspek kelayakan media yang meliputi: (1) teknik penyajian, (2) pendukung penyajian dan (3) penyajian pembelajaran.

Tabel 3. Hasil Analisis Validasi Modul Komponen

\begin{tabular}{|c|c|c|c|c|}
\hline \multicolumn{5}{|c|}{ Bahasa } \\
\hline \multicolumn{2}{|c|}{ Validator } & Skor & Rata & Kriteria \\
\hline \multirow{2}{*}{ Dosen } & Dosen 1 & 35 & \multirow{2}{*}{33} & \multirow{2}{*}{ Baik } \\
\hline & Dosen 2 & 31 & & \\
\hline \multirow{2}{*}{ Guru } & Guru 1 & 38 & \multirow{2}{*}{38,5} & Sangat \\
\hline & Guru 2 & 39 & & Baik \\
\hline \multirow{2}{*}{$\begin{array}{l}\text { Peer } \\
\text { Review }\end{array}$} & PRI & 38 & \multirow{2}{*}{40,5} & Sangat \\
\hline & $P R 2$ & 43 & & Baik \\
\hline \multicolumn{3}{|c|}{ Rata-rata Total } & 37,33 & $\begin{array}{c}\text { Sangat } \\
\text { Baik }\end{array}$ \\
\hline
\end{tabular}

Tabel 3. menunjukkan validasi modul pada komponen bahasa oleh setiap validator. Hasil validasi modul pada kelayakan bahasa diperoleh skor rata-rata total 37,33 dari skor maksimum 44 dengan kategori sangat baik. Skor diperoleh dari 5 komponen bahasa yang meliputi: (1) kelugasan bahasa (2) komunikatif (3) dialogis dan interaktif (4) kesesuaian dengan perkembangan peserta didik dan (5) kesesuaian dengan kaidah bahasa indonesia.

Uji Coba kecil modul fisika berbasis CTL materi dinamika partikel dilakukan pada 12 siswa kelas X MIA-3 SMAN 1 Ngawi. Uji coba kecil bertujuan untuk mengetahui kelayakan modul fisika berbasis CTL pada materi dinamika partikel. Hasil analisis uji coba kecil menyatakan bahwa nilai rata-rata berkategori baik. Draf II modul setelah diujicobakan, kemudian direvisi sehingga diperoleh draf III Modul.

Uji coba lapangan dilakukan setelah draf II direvisi dan dihasilkan draf III modul. Uji coba lapangan dilakukan pada 30 siswa kelas X MIA-1 SMAN 1 Ngawi untuk mengetahui peningkatan keterampilan berpikir kritis siswa. Sebelum modul fisika berbasis CTL diimplementasikan dalam pembelajaran fisika, siswa diberikan pretest terlebih dahulu dan siswa diberikan posttest setelah kegiatan pembelajaran menggunakan modul fisika berbasis CTL.
Histogram distribusi keterampilan berpikir kritis siswa dapat dilihat pada Gambar 1.

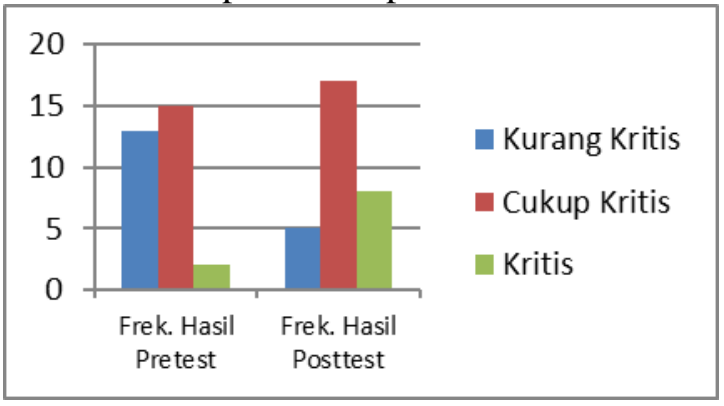

Gambar 1. Histogram Keterampilan Berpikir Kritis Saat Pretest dan Postest

Penguasaan konsep fisika sebagai aspek pengetahuan pada penelitian ini diperoleh melalui prestest dan postest yang secara tidak langsung mengukur keterampilan berpikir kritis siswa. Berdasarkan Gambar 1, pada saat pretest siswa dengan kategori kurang kritis berjumlah 13 siswa, cukup kritis 15 siswa, dan kategori kritis 2 siswa. Sedangkan pada saat posttest, siswa dengan kategori kurang kritis 5 siswa, cukup kritis 17 siswa, dan kritis 8 siswa. Peningkatan penguasaan konsep fisika diketahui dengan melakukan uji prasyarat berupa uji normalitas dan homogenitas sebagai penentu uji statistik selanjutnya. Uji prasyarat menunjukkan bahwa data berdistribusi normal dan homogen, sehingga langkah selanjutnya yaitu dengan menggunakan uji paired sample t-test.

Berdasarkan uji paired t test diperoleh Asyimp. Sig (2-tailed) kurang dari 0,05 yaitu 0,000 yang berarti $\mathrm{H}_{0}$ ditolak, sehingga diperoleh kesimpulan ada perbedaan rata-rata penguasaan konsep fisika siswa sebelum dan sesudah menggunakan modul fisika berbasis CTL. Besarnya peningkatan penguasaan konsep fisika sebelum dan setelah penerapan modul fisika berbasis CTL dianalisis dengan persamaan gain faktor ( $N$-Gain).

Tabel 4. Deskripsi Peningkatan Penguasaan Konsep

\begin{tabular}{ccccccc}
\multicolumn{7}{c}{ Fisika } \\
$\begin{array}{c}\text { Jenis } \\
\text { Test }\end{array}$ & $\begin{array}{c}\text { Jumlah } \\
\text { siswa }\end{array}$ & Mean & SD & Min & Mak & Gain \\
\cline { 1 - 6 } Pretest & 30 & 58,42 & 6,36 & 47,74 & 72,38 & 0,36 \\
\cline { 1 - 6 } Postest & 30 & 73,87 & 6,27 & 60,06 & 84,7 & \\
\hline
\end{tabular}

Tabel 4 mendeskripsikan skor pretest berupa data pengusaan konsep fisika siswa sebelum diberikan pembelajaran menggunakan modul fisika berbasis CTL dengan rata-rata 58,42 dan skor posttest berupa data 
penguasaan konsep fisika siswa setelah diberikan pembelajaran menggunakan modul fisika berbasis CTL dengan rata-rata 73,87. Data tersebut menunjukkan adanya peningkatan rata-rata penguasaan konsep fisika setelah kegiatan pembelajaran dengan modul fisika berbasis CTL. Peningkatan siswa terhadap penguasaan konsep fisika setelah dilakukan pembelajaran dengan modul fisika berbasis CTL sebesar 0,36 dengan kategori sedang, sehingga keterampilan berpikir kritis setelah dilakukan pembelajaran dengan modul fisika berbasis CTL meningkat relatif sedang.

Setelah siswa mengikuti pembelajaran dengan modul fisika berbasis CTL, siswa diberi angket respon siswa. Hasil analisis angket respon siswa pada uji coba besar yang terdiri dari 30 siswa didapatkan kesimpulan bahwa modul fisika berbasis CTL berkategori sangat baik.

Hasil tahap penyebaran (Disseminate) dilakukan setelah diperoleh produk berupa modul fisika berbasis CTL yang valid dan efektif untuk meningkatkan keterampilan berpikir kritis siswa. Penyebaran produk berupa modul fisika berbasis CTL dilakukan pada 5 guru fisika SMA yang mengajar siswa kelas X di Ngawi Jawa Timur. Penyebaran dilakukan dengan memberikan modul fisika berbasis CTL materi dinamika partikel pada guru-guru fisika, kemudian diberikan angket untuk mengetahui respon guru terhadap modul yang telah dikembangkan.

Angket respon guru terhadap modul fisika berbasis CTL materi dinamika partikel meliputi aspek efektifitas (kesesuaian) waktu penggunaan modul fisika berbasis CTL, tingkat kesulitan penggunaan modul, daya tarik tampilan modul, tingkat kesesuaian gambar dengan materi dinamika partikel, masalah yang disajikan melingkupi kegiatan sehari-hari, persoalan yang disajikan dapat menumbuhkan keterampilam berpikir kritis, daya tarik keseluruhan modul, daya tarik penyampaian materi pada modul, kemudahan dalam pemahaman materi pada modul, dan kesenangan menggunakan modul fisika berbasis CTL. Berdasarkan hasil angket respon guru didapatkan kesimpulan bahwa modul fisika berbasis CTL kategori sangat baik.

\section{Pembahasan}

Tahap pendefinisian (Define) dalam penelitian ini dilakukan untuk mengidentifikasi masalah-masalah yang ada di lapangan melalui studi pustaka dan survei di SMAN 1 Ngawi sebagai analisis kebutuhan awal terhadap produk yang akan dikembangkan.

Salah satu materi fisika yang diajarkan di kelas X di SMAN 1 Ngawi adalah dinamika partikel. Sesuai dengan rencana penelitian, materi dinamika partikel diajarkan di semester 1. Alasan dipilih materi dinamika partikel karena materi tersebut bersifat kontekstual dan memiliki banyak aplikasi langsung dalam kehidupan sehari-hari.

Berdasarkan analisis kebutuhan awal diketahui guru mengalami kesulitan mengajarkan materi dinamika partikel. Kesulitan mempelajari materi dinamika partikel dan kurangnya antusias siswa mengikuti pembelajaran masing-masing sebanyak $70 \%$. Materi dinamika partikel bersifat kontekstual, namun 53\% siswa menyatakan jarang diajarkan untuk mengaplikasikan konsep yang telah diperolehnya dalam kehidupan sehari-hari, sehingga belajar fisika hanya sekedar mengumpulkan konsep tanpa manfaat dalam konteks nyata.

Selama kegiatan belajar fisika di kelas $\mathrm{X}$ siswa jarang terlibat dalam kegiatan laboratorium untuk melakukan eksperimen, hal ini menunjukkan bahwa konsep-konsep yang diperoleh siswa tidak diperoleh secara scientific melainkan mengumpulkan konsepkonsep yang diberikan oleh guru melalui ceramah atau rangkuman materi yang diberikan guru kepada siswa dan latihan soal. Pembelajaran yang demikian menyebabkan kejenuhan siswa belajar fisika di kelas, karena siswa beranggapan bahwa belajar fisika tidak lebih dari mengerjakan soal-soal latihan berupa hitung-hitungan menggunakan rumus yang rumit. Belajar fisika hanya berorientasi pada hasil belajar, maka siswa belum diajarkan untuk mengembangkan keterampilan berpikir kritis yang sebenarnya jauh lebih penting sebagai bekal dalam kehidupan nyata, sebagaimana yang diungkapkan oleh Howard Gardner cit. Jasmine (2007: 16) bahwa, 
"Keberhasilan di sekolah bukan alat peramal yang baik bagi keberhasilan siswa dalam kehidupan yang sebenarnya kelak." Karena belajar tidak hanya sekedar mengumpulkan konsep-konsep, tetapi menggunakan konsepkonsep yang telah mereka pelajari untuk menyelesaikan masalah yang dihadapi dalam kehidupan nyata.

Hanya sebagian siswa yang mempunyai buku pegangan untuk belajar dan belum ada guru yang menggunakan modul sebagai sumber belajar mandiri bagi siswa, sehingga guru adalah sumber belajar utama. Untuk mengatasi permasalahan yang telah diuraikan di atas maka guru dan siswa membutuhkan modul cetak sebagai sumber belajar. Pengembangan modul bertujuan menyediakan sumber belajar yang selama ini belum banyak tersedia. Modul juga membantu siswa dalam belajar, hal ini seperti yang diungkapkan oleh Dimitrios I. Dimopoulos (2009) dalam hasil penelitiannya bahwa modul memberikan pengaruh yang signifikan terhadap keterampilan kognitif dan sikap siswa.

Dinamika partikel merupakan salah satu materi fisika yang kontekstual dan memiliki banyak aplikasi di lingkungan sekitar, oleh karena itu modul yang dikembangkan juga berbasis pembelajaran kontekstual yang menanamkan sikap dan keterampilan yang mampu menumbuhkan keterampilan berpikir kritis agar tercapainya tujuan pendidikan nasional. Modul yang dikembangkan menerapkan strategi pembelajaran yang mengajak siswa untuk belajar secara kontekstual.

Modul yang dikembangkan dirancang untuk memenuhi ketersedian sumber belajar kurikulum 2013 dengan pembelajaran CTL. Kompetensi inti yang diambil adalah KD 1.1, KD 1.2, KD 2.1, KD 2.2, KD 3.4 dan KD 4.4 dengan materi dinamika partikel. Alasan dipilih materi dinamika partikel karena materi tersebut bersifat kontekstual dan memiliki banyak aplikasi langsung dalam kehidupan sehari-hari. Materi dinamika partikel meliputi hukum I, II dan III Newton yang penerapannya dapat ditemui dalam kehidupan sehari-hari.
Fisika yang merupakan salah satu cabang dari ilmu sains yang memiliki karakteristik untuk diajarkan dengan cara mencari tahu untuk memahami konsep sains. Langkah yang digunakan untuk memahami konsep sains adalah dengan mencari tahu sendiri ilmu pengetahuan. Berdasarkan analisis yang telah diperoleh, dalam belajar siswa masih sekedar mengumpulkan konsep dan kurang memaknai pembelajaran sains maka metode yang tepat adalah dengan mengembalikan karakter ilmu sains, yaitu dengan pendekatan scientific salah satunya adalah pendekatan kontekstual (CTL).

Fitri (2013) menyatakan hasil penelitiaannya bahwa modul fisika dengan pendekatan kontekstual dapat mengoptimalkan minds-on siswa. Tural (2013) menyatakan hasil penelitiannya bahwa pembelajaran kontekstual memberikan pengaruh yang positif terhadap sikap siswa pada mata pelajaran fisika, karena pembelajaran kontekstual tidak sekedar menghafal teori sehingga tidak mudah dilupakan. Pembelajaran secara kontekstual memberikan informasi yang permanen dengan membangun hubungan antara fisika dan kehidupan sehari-hari.

Tahap perancangan (Design) dengan pemilihan format modul yang diadaptasi dari kriteria modul yang diterbitkan oleh Pusat Teknologi Informasi dan Komunikasi Pendidikan Depdiknas (2007: 28), bahwa komponen modul terdiri dari pendahuluan, bagian inti, dan penutup. Bagian pendahuluan terdiri dari deskripsi modul dan tujuan pembelajaran, prasyarat, rencana belajar siswa, petunjuk penggunaan modul, bagian-bagian modul, dan peta konsep. Bagian inti terdiri dari materi prasyarat, kegiatan pembelajaran hukum I, II, dan III Newton. Bagian penutup terdiri dari rangkuman, evaluasi, glosarium, daftar pustaka, dan kunci jawaban.

Teknik penyusunan modul dalam penelitian ini diadaptasi dari teknik yang disampaikan oleh Pusat Teknologi Informasi dan Komunikasi Pendidikan (Pustekkom) Depdiknas (2007: 10) yaitu teknik menulis sendiri. Penulis menggunakan berbagai buku dan sumber informasi lain sebagai dasar dalam menulis modul, sehingga terjadi keterpaduan 
isi berdasarkan pengetahuan penulis dan sumber informasi yang telah ada. Modul ditulis berdasarkan kurikulum 2013, satuan acara pembelajaran, dan garis-garis besar isi modul (GBIM).

GBIM digunakan sebagai pedoman penyusunan modul yang dikembangkan dalam penelitian ini berisi judul modul, kompetensi inti, indikator, materi pokok, rincin materi, penilaian, dan sumber pustaka. Setelah ditetapkan GBIM selanjutnya membuat outline atau rancangan modul berupa gambaran umum dari modul yang akan dikembangkan dalam penelitian. Outline dalam penelitian ini berisi gambaran umum kegiatan pembelajaran dari kegiatan kontruktivisme (constructivism), penemuan (inquiry), bertanya (questioning), komunitas belajar (learning community), pemodelan (modeling), refleksi (reflection) dan penilaian sebenarnya (authentic assessment) di setiap kegiatan pembelajaran sehingga dihasilkan modul fisika berbasis CTL.

Modul berbasis CTL yang dibuat memuat gambaran mengenai konsep-konsep dinamika partikel, pada setiap kegiatan pembelajaran siswa akan dituntun untuk mencari tahu konsep yang akan diperolehnya melalui pengalaman langsung (constructivism) diantaranya melalui eksperimen, kejadian yang sudah pernah dialami maupun melalui pengamatan kejadian sehari-hari. Pada setiap kegiatan belajar siswa akan disajikan model (modelling) mengenai konsep hukum Newton, kemudian siswa diminta membuat pertanyaan (questioning) yang berhubungan dengan model yang telah ditunjukkan. Masalah yang ditemui siswa kemudian diselesaikan secara bersamasama dalam kelompok kecil (learning community) melalui eksperimen, disini siswa dituntut untuk bekerja dalam sebuah tim untuk menyelesaikan masalah yang didapatnya hingga didapatkan solusi (inquiry). Langkah selanjurnya adalah presentasi untuk membahas hasil eksperimen. Setelah presentasi selesai, guru bersama siswa merefleksi (reflection) hasil dari pembelajaran dan presentasi. Hingga pada akhir pembelajaran dilakukan tes untuk mengetahui pemahaman siswa mengenai materi yangtelah dipelajari (authentic assesment).
Tahap pengembangan (Develop) berupa validasi dan uji coba kecil. Validasi dilakukan untuk mengetahui kualitas modul fisika berbasis CTL yang dikembangkan. Menurut Daryanto (2013: 22) modul dikatakan valid jika isi modul sesuai atau efektif untuk mempelajari kompetensi yang menjadi target belajar. Validasi modul dilakukan dengan cara meminta bantuan ahli yang menguasai kompetensi yang dipelajari dengan cara membaca cermat isi modul. Validasi modul dalam penelitian ini dilakukan pada komponen materi, media dan tata bahasa oleh 2 dosen ahli, 2 guru fisika SMA, dan 2 teman sejawat yang mengembangkan modul pembelajaran.

Uji coba kecil dilakukan pada 12 siswa kelas XI MIA-3 SMAN 1 Ngawi di semester ganjil tahun ajaran 2014/2015 dengan mempelajari draf II modul. Uji coba kecil digunakan untuk mengumpulkan informasi guna memperbaiki draf II modul. Uji coba kecil dilakukan satu kali pertemuan dengan membagi 12 siswa menjadi 3 kelompok untuk mempelajari draf II modul. Di akhir kegiatan siswa diberi angket respon. Hasil uji respon siswa pada uji coba kecil diperoleh kesimpulan bahwa modul dikategorikan baik sehingga layak digunakan untuk diujicoba lapangan. Setelah draf II modul diperbaiki maka diperoleh draf III modul yang siap diujicobakan secara empiris realistis di lapangan.

Uji coba lapangan dilakukan pada 30 siswa kelas X MIA-1 SMA Negeri 1 Ngawi disemester ganjil tahun ajaran 2014/2015. Uji coba lapangan dilakukan selama 3 kali pertemuan di luar jadwal pretest dan posttest. Menurut Daryanto (2013: 52) uji coba lapangan dilakukan untuk mengumpulkan informasi yang belum diperoleh dari uji coba kecil dalam upaya penyempurnaan modul. Dalam penelitian ini uji coba besar dilakukan untuk melihat peningkatan keterampilan berpikir kritis siswa sebelum dan sesudah menggunakan modul fisika berbasis CTL, baik selama mengikuti pembelajaran ataupun setelah mengikuti pembelajaran menggunakan modul.

Sebelum kegiatan belajar di mulai siswa dibagi menjadi 7 kelompok secara acak. 
Pembagian kelompok secara acak bertujuan menghindari pilih-pilih teman yang sudah mereka kenal dalam belajar, siswa diajari untuk bekerja sama dengan orang-orang yang memiliki berbagai kepribadian, jenis kelamin, dan latar belakang. Hal inilah yang mengajarkan siswa untuk bersosialisasi dengan orang lain ketika hidup bermasyarakat tanpa membedakan ras, kedudukan, dan status ekonomi. Pembentukan kelompok secara acak mengajarkan siswa untuk membentuk kecerdasan antarpribadi atau interpersonal sebagaimana yang diungkapkan oleh Gardner (2013: 48) bahwa kecerdasan antarpribadi dibangun atas dasar kemampuan untuk mengenali perbedaan secara khusus, berbedaan besar dalam suasana hati, temperamen, motivasi, dan kehendak. Selain itu manfaat belajar secara berkelompok diungkapkan dalam hasil penelitian Huda (2013) bahwa pembelajaran kooperatif berpengaruh positif terhadap hasil belajar siswa pada ranah kognitif, psikomotor, dan afektif dengan koefisien korelasi sebesar 0,814 . Selanjutnya Ahmad dan Mahmood (2010) menambahkan bahwa hasil penelitiannya dengan pembelajaran kooperatif mampu meningkatkan prestasi akademik mahasiswa calon guru serta memberikan pengalaman belajar yang menyenangkan dan interaktif.

Peningkatan keterampilan berpikir kritis pada penguasaan konsep sebelum dan sesudah menggunakan modul fisika berbasis CTL dapat dilihat dari nilai pretest dan posttest siswa. Peningkatan siswa terhadap penguasaan konsep fisika setelah dilakukan pembelajaran dengan modul fisika berbasis CTL meningkat relatif sedang, sehingga penerapan modul fisika berbasis CTL cukup efektif untuk meningkatkan keterampilan berpikir kritis siswa.

Keterampilan berpikir kritis dapat meningkat karena siswa diberikan kesempatan untuk terlibat aktif dalam pembelajaran. Hal ini sesuai dengan hasil penelitian Ahmat Zeki Saka (2011) dan G. Tural (2013) bahwa penerapan modul fisika berbasis CTL sebagai media ajar dalam pembelajaran fisika memberikan kesempatan kepada siswa untuk terlibat aktif dalam kegiatan belajar.
Tahab penyebaran (Desseminate) merupakan tahap akhir dari 4-D. Setelah draf III modul fisika berbasis CTL diujicobakan pada skala besar maka diperoleh modul fisika berbasis CTL yang siap disebarluaskan pada guru-guru fisika. Penyebaran produk dilakukan pada 5 guru Fisika kelas X SMA di kabupaten Ngawi Jawa Timur. Hasil penyebaran produk diperoleh rata-rata skor total 34,4 dari skor maksimum 40 dengan kategori sangat baik. Modul fisika berbasis CTL secara umum diyakini efektif sebagai media pembelajaran untuk menguasai kompetensi yang menjadi target belajar.

Marlina (2011) menyatakan bahwa model Contextual Teaching and Learning pada perkuliahan tata kecantikan wajah dan rambut yang memadukan berbagai strategi pembelajaran meningkatkan kemampuan kreativitas mahasiswa khususnya pada program studi pendidikan tata busana, terutama peningkatan kreativitas mahasiswa untuk membentuk dan mengembangkan konsep pada diri mahasiswa dengan cara aplikasi ilmu dalam kehidupan sehari-hari. Senada dengan Marlina, penelitian Yulianto (2011) dengan hasil analisis data kualitatif menunjukan bahwa baik aktivitas guru, aktivitas siswa dan respon siswa terhadap KBM yang dilaksanakan berdasarkan CTL menunjukan tingkat pencapaian yang baik, demikian juga dengan pelaksanaan tujuh komponen utama dari CTL. Hasil post-test juga menunjukan peningkatan yang signifikan, hasil nilai yang sesuai SKBM (nilai 66) berdasarkan metode konvensional sebesar 45 $\%$, sedangkan berdasar metode CTL sebesar 70 $\%$. Adapun hasil uji beda antara pelaksanaan post-test dikelas percobaan dan kelas tindakan menunjukan terdapat perbedaan hasil belajar siswa.

\section{Kesimpulan dan Rekomendasi}

Berdasarkan hasil analisis data dan pembahasan yang telah dilakukan dapat disimpulkan sebagai berikut.

Modul Fisika berbasis CTL pada materi dinamika partikel dikembangkan dengan model 4-D meliputi define, design, 
develop, dan disseminate. Pada setiap kegiatan belajar siswa akan disajikan kegiatan pembelajaran dengan disajikan materi mengenai hukum Newton (Constructivism), siswa diberikan model berupa gambar yang berkaitan dengan materi ajar sehingga siswa menemukan masalah dengan mengajukan pertanyaan (Modelling dan Quetioning), siswa diajak untuk belajar secara berkelompok untuk menemukan solusi atas masalah yang diberikan (Learning Community dan Inquiry), siswa diajak untuk mengulas kembali materi yang telah dipelajari dengan membuat rangkuman (Reflection), di akhir kegiatan siswa diberikan soal mengenai materi yang telah dipelajari untuk diambil penilaian sejauh mana pemahaman siswa terhadap materi yang diberikan (Authentic Assessment).

Modul pembelajaran fisika berbasis CTL pada materi dinamika partikel divalidasi pada komponen materi, kegrafikan atau media dan bahasa oleh 2 dosen, 2 guru, dan 2 peer review. Hasil validasi untuk komponen materi, media dan bahasa diperoleh kesimpulan bahwa modul berbasis CTL memperoleh kategori sangat baik. Sedangkan dari hasil uji coba kecil menunjukkan bahwa modul fisika berbasis CTL pada materi dinamika partikel mendapat kategori baik. Berdasarkan hasil validasi dan respon uji coba kecil maka modul pembelajaran fisika berbasis CTL pada materi dinamika partikel layak digunakan untuk meningkatkan keterampilan berpikir kritis siswa.

Modul fisika berbasis CTL pada materi dinamika partikel dapat meningkatkan kemampuan berpikir kritis siswa. Hal ini terlihat dari hasil perbandingan preetest dan posttest yang diberikan pada siswa. Hasil $\mathrm{N}$ gain menunjukkan kesimpulan bahwa modul pembelajaran fisika berbasis CTL dapat meningkatkan keterampilan berpikir kritis dengan kategori sedang.

Modul fisika berbasis CTL pada materi dinamika partikel disarankan untuk dimanfaatkan oleh guru fisika secara luas dalam pembelajaran untuk meningkatkan kemampuan berpikir kritis siswa. Kegiatan eksperimen yang ada dalam modul hendaknya benar-benar dilaksanakan untuk melatih siswa terbiasa dengan kegiatan laboratorium dan penemuan.

Hasil penelitian ini dapat digunakan sebagai acuan untuk mengembangkan penelitian sejenis pada materi yang berbeda. Untuk meningkatkan keterampilan berpikir kritis siswa lebih baik lagi hendaknya dilakukan dalam waktu yang cukup lama, karena keterampilan berpikir kritis siswa membutuhkan proses untuk tumbuh dari lingkungan yang mendukung. Pada tahap penyebaran, produk yang dikembangkan dapat disebarkan lebih luas lagi sehingga produk mudah dikenal oleh banyak peminat untuk dimanfaatkan dalam pembelajaran.

\section{Daftar Pustaka}

Ahmad dan Mahmood. (2010). Effect of Cooperative Learning vs Traditional Instruction on Perspective Teachers Learning Experience and Achievement. Journal of Edication Sciences.43 (1);151164.

Ahmat, Zeki (2011). Investigation Of Student Centered Teaching Application of physics Student Teachers. Eurasian Journals. Caradenist Technical University.

BSNP. (2006). Permendiknas No. 22 Tahun 2006 Tentang Standart Isi Untuk Satuan Pendidikan Dasar dan Menengah. Jakarta: Depdiknas

Daryanto. (2013). Strategi dan Tahapan Belajar. Bandung: CV. Yrama Widya.

Depdiknas. (2007). Pedoman Memilih Menyusun Bahan Ajar dan Teks Mata Pelajaran. Jakarta: BP. Mitra Usaha Indonesia.

Dimitrios I. Dimopoulos. (2009). Planning Educational Activities and Teaching Strategies on Constructing a Conservation Educational Module. International Journal of Environmental \& Science Education. 4 (4): 351-354

Fitri, Lidy Alimah. (2013). Pengembangan Modul Fisika pada Pokok Bahasan Listrik Dinamis Berbasis Domain Pengetahuan Sains untuk Mengoptimalkan Minds-On Siswa SMA Negeri 2 Purworejo Kelas X 
Tahun Pelajaran 2012/2013. Jurnal Radiasi. 3 (1); 4-6

Gardner, Howard. (2013). Multiple Intelligences: Memaksimalkan Potensi dan Kecerdasan Individu dari Masa Kanak-Kanak Hingga Dewasa. Jakarta: Daras.

Gunawan; Setiawan, A; Rusdiana, D. (2008). Model Pembelajaran Berbasis Multimedia Interaktif untuk Meningkatkan Keterampilan Generik Sains Calon Guru Pada Materi Elastisitas. Jurnal Penelitian Pendidikan IPA. 2 (1);11-12

Hamdani. (2011). Strategi Belajar Mengajar. Pustaka Setia: Bandung.

Huda, Miftachul. 2013. Cooperative Learning Metode, Teknik, Strutur, Model Penerapan. Yogyakarta: Pustaka Pelajar.

Jasmine, Julia. (2007). Mengajar dengan MetodeKecerdasan Majemuk Implementasi Multiple Intelligences. Bandung; Penerbit Nuansa.

Marlina. (2011). Model Contextual Teaching And Learning (CTL) Pada Perkuliahan Dasar Rias (Tata Kecantikan Wajah Dan Rambut) Untuk Meningkatkan Kreativitas Mahasiswa. Jurnal Penelitian Pendidikan. $12(1) ; 4-6$

Megarati. (2010). "Peningkatan Hasil Belajar Matematika Pada Materi Turunan Fungsi Menggunakan Teknik Probing Prompting di Kelas XI IPA 1 di Kelas Menengah Atas Negeri 2 Palembang”. Tesis. Tidak Diterbitkan. FKIP Unsir.

Muhfahroyin. (2009). Memberdayakan Kemampuan Berpikir Kritis Siswa Melalui Pembelajaran Kontruktivis. Jurnal Pendidikan dan Pembelajaran. 16 (1); 8893

Munandar, Utami. (2009). Pengembangan Kreativitas Anak Berbakat. Jakarta: Rineka Cipta

Muslich, Masnur. (2007). KTSP Pembelajaran Berbasis Kompetensi dan Kontekstual Panduan bagi Guru, Kepala Sekolah dan Pengawas Sekolah. Jakarta: Bumi Aksara.

Permendikbud. (2013). Peraturan Menteri Pendidikan dan Kebudayaan Nomor 69 Tahun 2013 Tentang Kurikulum SMA. Jakarta: Diknas
Rofiudin, A. (2010). Model Pendidikan Berpikir Kritis -Kreatif Untuk Siswa Sekolah Dasar. Majalah Bahasa dan Seni

Suaidinmath. (2010). Teknik Penyusunan Modul (http://suadinmath.wordpress.com, di akses 20 Juni 2014)

TIMSS. (2011). Highligths from TIMSS 2007: Mathematics and Science Achievament of u.s. Fourth-and Eigth Grade Students In An International Context. Boston: TIMSS \& PIRLS International Study Center.

Tural, Guner. (2013). The Functioning of ContextBased Physics Instruction in Higher Education. Asia-Pacific Forum on Science Learning and Teaching. 14, Issue 1, Article 4.

Wirta dan Rapi. (2008). Pengaruh Model Pembelajaran dan Penalaran Formal Terhadap Penguasaan Konsep Fisika dan Sikap IlmiahSiswa SMAN 4 Sangaraja. Jurnal Penelitian dan Pengembangan Pendidikan. 1 (2); 15-29

Yulianto, Agung. (2011). Peningkatan Hasil Belajar Siswa dalam Mata Pelajaran Ekonomi melalui Pendekatan Pembelajaran Kontekstual (Contextual Teaching and Learning) pada SMA Negeri 11 Semarang. Jurnal Akuntansi Jurusan Akuntansi FE UNNES. $12 \quad$ (1); 14-16. 